\title{
A MAGYARORSZÁGI MAGÁNTULAJDONÚ ERDŐK TULAJDONSZERKEZETE
}

\author{
Mertl Tamás és Schiberna Endre \\ Nemzeti Agrárkutatási és Innovációs Központ, Erdészeti Tudományos Intézet
}

\begin{abstract}
Kivonat
Jelen közlemény alapja a magyarországi, nem állami tulajdonú, erdő művelési ágú területek teljes körü tulajdoni adatbázisa. Az adatbázis feldolgozása során megismert, fontos tulajdonszerkezeti jellemzők leírása található meg a tanulmányban, úgymint a földrészletek gyakorisági és területeloszlása a földrészleten belüli erdőterület és tulajdonosi létszám szerint, valamint a tulajdoni illetőségek gyakorisági és területeloszlása a tulajdoni illetőségek erdőterülete és szerzési jogcíme szerint. A lefolytatott vizsgálatok alapján az írás megállapítja, hogy a legfontosabb földforgalmi tényezök az öröklés és az adásvételek, amelyek bemutatása számszerü adatokkal is megtörténik. Elemzés olvasható a földrészleten belüli döntéshozatallal és a földrészleten belüli tulajdoni szerkezet koncentráltságával kapcsolatban.
\end{abstract}

Kulcsszavak: tulajdoni illetőség, szerzési jogcím, öröklés, tulajdon koncentráció, földforgalom.

\section{PROPERTY STRUCTURE OF PRIVATE FORESTS IN HUNGARY}

\begin{abstract}
This paper is based on a database of land lots that are not state owned and are classified as forest in the land registry in Hungary. A description of major parameters of ownership structure can be found in this article such as the area and frequency distribution of land lots over the size of forest area within the land lots and the number of owners of the land lots, as well as the area and frequency distribution of the ownership titles over the size of area of the ownership title and the title deed types. Based on the analysis of the dataset it has been proven that the most important forms of land transactions are purchasing and inheriting, of which the numerical description is also presented. The paper contains an analysis regarding decision making within the land lots, and regarding the inequality of ownership distribution.
\end{abstract}

Keywords: ownership title, ownership title deed, inheriting, concentration of property, land transactions. 


\section{BEVEZETÉS ÉS CÉLKITŰZÉS}

\section{A tulajdonosok jelentősége}

A magánerdők müködésének megértéséhez és a kapcsolódó szabályozások kialakításának érdekében alapvető fontosságú a tulajdoni és tulajdonosi viszonyok ismerete. Ennek oka az, hogy a magán-erdőgazdálkodás kiindulási alapja a tulajdonosi döntés, amely meghatározza a magánerdők hasznositásának céljait és szervezeti kereteit.

Európában és különösen az Európai Unió országaiban igen elterjedt a magántulajdonú erdőgazdálkodás, amelyen belül nagy szerepet kap az egyéni és a családi erdőgazdálkodás. Az európai erdők körülbelül fele magántulajdonú erdő, aminek $82 \%$-át teszi ki az egyének vagy családok tulajdonában lévő erdő (közelítőleg 52 millió hektár). Ezen erdők gazdasági jelentőségét jól jellemzi, hogy számos országban a belölük kitermelt faanyag mennyisége meghaladja az állami erdőkből kitermelt faanyagét, még úgy is, hogy sok esetben alacsonyabb a magánszektorban a fakitermelési lehetőségek kihasználtsága. Elmondható az is, hogy a magánerdőkben kitermelt faanyag nagyobb része tüzifa, mint az állami erdők esetében, valamint a minősített erdőterület aránya is jóval elmarad az államiétól (Schmithüsen \& Hirsch 2008).

A családi gazdaságokban a tulajdonos és az erdőgazdálkodó személye megegyezik, vagy legalább rokonsági kapcsolatban állnak. $E$ hagyományos gazdálkodási modell mellett új típusú tulajdonosok is megjelennek, legföképpen a tradicionális mezőgazdaság háttérbe szorulásának hatására. Az új típusú erdőtulajdonosok alatt általában az agrár háttérrel nem rendelkező tulajdonosokat értik, akiknek sok esetben mások az elképzeléseik az erdejükkel kapcsolatban. Elkülöníteni ezeket a tulajdonosokat a korábbi szerzők írásai szerint három fő szempont alapján lehet: az erdőtulajdonuk jellege; általános értékrendjük, viselkedésük és céljaik; az erdöhöz való viszonyuk és céljaik az erdejükkel. Számos korábbi írás próbálta bizonyos szempontok szerint kategorizálni a tulajdonosokat, erre példa Hogl et al (2005) írása, akik a fent leírt szempontrendszer szerint 7 csoportot különítettek el. Ezek között megjelentek az „új típusú” tulajdonosok is, mint például a városi erdőtulajdonosok, vagy az erdőtulajdonosok agrár háttér nélkül. Ezen tulajdonosok esetében jellemzően alacsony az erdöből származó bevételek aránya az egyéb bevételeikhez képest, és kevéssé függ az anyagi boldogulásuk az erdejük használatától (Hogl et al 2005). Meg kell jegyezni, hogy a számos hasonló célú kutatás ellenére mindmáig egységes koncepció erre a célra még nem alakult ki, és az eddigi főként Nyugat- és Észak-európai minták a magyar magánerdőkre a különböző történelmi háttér miatt csak korlátozottan alkalmazhatók.

Magyarországon a magántulajdonú erdők az 1990-es évek első felében lezajlott többéves magánositási folyamat által jöttek újra létre. Feltételezhetjük, hogy az erdőgazdálkodási gépek és az élö erdőgazdálkodási hagyományok hiánya, valamint a gyenge fapiaci kereslet mellett a kedvezőtlen tulajdonviszonyok is hátráltatták a magán-erdőgazdálkodás fejlődését. Mindezeken felül a jogi szabályozáson keresztül az erdészeti politika igyekezett az 
új tulajdonosokat társult gazdálkodásra késztetni. Az 1996 évi erdőtörvény a többtulajdonosú, természetben egybefüggő erdők esetén társult erdőgazdálkodást írt elő 1998-ig (1996. évi LIV. tv., 13. § 4a). Ugyanezen törvényben szerepel, hogy „Az erdőgazdálkodási tevékenység szakszerűségének biztositása érdekében az állam támogatja az erdőtulajdonosok társult erdőgazdálkodási tevékenységét" (Evt. 1996). A 2009 évi erdőtörvény társult erdőgazdálkodást ír elö, ha a földrészletnek több tulajdonosa van, vagy az erdőrészlet több földrészleten fekszik, melyek tulajdonosa nem azonos (2009. évi XXXVII. tv., 17§, 6-7). A társult erdőgazdálkodás elöírása részben szükséghelyzet, részben azonban a nagyobb gazdálkodási egységek kialakulását és az egyéni tulajdonosi érdekek korlátozását célozza meg. A két erdőtörvény mellett e célokra való törekvés érezhető az erdőbirtokossági társulatról szóló törvényben is, miszerint természetben egybefüggő területen az erdőbirtokossági társulat nem utasíthatja vissza új tag jelentkezését (1994. évi XLIX. törvény az erdőbirtokossági társulatról, 25. §. 2).

A tulajdoni szerkezet és a tulajdonosok ilyen általános érvényű és mélyreható jelentősége ellenére nem rendelkezünk megfelelö adatokkal. A privatizáció lezajlása óta már többen is foglalkoztak a témával. Még a privatizáció részben zajlott, amikor Páll (1997) az árverési adatok alapján megvizsgálhatta Zala megyében 12000 hektáron, 3244 földrészleten a privatizáció során kialakult tulajdonszerkezetet. Bár a rendelkezésre álló adatai hiányosak voltak, megállapíthatta, hogy a keletkező átlagos tulajdoni illetőség 0,47 ha körül alakult, valamint azt, hogy a legtöbben összesen 1-5 hektár erdőt szereztek, általában több földrészleten. Emellett azt is tapasztalta, hogy a földrészletek $40 \%$-án csak egy tulajdonos került bejegyzésre, de ez csupán a terület 6\%-át jelentette, a terület 63\%-án pedig 10-nél több tulajdonosú közös tulajdon jött létre.

Jáger (2001) az erdőtulajdonosok ismereteit vizsgálta, valamint jellemezte őket számos szempont szerint, 2050 fős minta segítségével. A munkájából kiderül, hogy a 90-es évek végén az átlag életkor az erdőtulajdonosok között körülbelül 50-60 év, a tulajdonosok 70\%a férfi, közel 60\%-uk szakmunkás, vagy 8 általánost végzett, alacsony jövedelmü és $75 \%$ uknak 5 ha alatti birtoka van. Az is kiderült, hogy a többség a tüzifa termelés, vagy a kárpótlási jegy befektetése céljából vett erdőt. A szerző kiemeli, hogy a teljes tulajdonosi kör nagyon heterogén, ezért további csoportok képzése lenne indokolt.

Mészáros (2001) a városi erdőtulajdonosok jellemzőit és elképzeléseit vizsgálva azt állapitotta meg, hogy a városi erdőtulajdonosok többségének kevésbé fontos az erdő gazdasági szempontból, mint a vidéki tulajdonosoknak, az ismereteik az eltelt idő alatt nem sokat változtak, ezért sokkal nagyobb hajlandóságot mutatnak a közös gazdálkodásra és kevéssé érzékenyek a gazdálkodó kilétére, mint a vidéki tulajdonosok.

A magán-erdőgazdálkodás, miközben alapvető problémákkal - mint például a tulajdonosi és gazdálkodói szerkezet - küzd, a vidékfejlesztés egyik célterülete is. Ezzel összefüggésben a természetvédelmi és közjóléti célok megvalósitására, valamint a vállalkozások fejlesztésére a magán-erdőgazdálkodásban is jelentős programok indultak. A legegyszerübb fejlesztési projektektől az olyan mélyreható változásokig, mint például a folyamatos erdőborítás 
bevezetése, a vidékfejlesztésnek és az erdészeti politikának is szembe kell néznie a tulajdonszerkezeti problémákkal és azok messze ható következményeivel (Lett et al 2016).

\section{Célkitűzések}

A fent leírtak szerint mind a további tudományos kutatások, mind pedig az ágazati szereplők munkája számára lényeges a témával kapcsolatos alapvető adatok megismerése, ezért jelen írás egyik célja a magántulajdonú, erdő művelési ágú földrészletek jellemzőinek bemutatása. Emellett megvizsgáljuk azokat a témába vágó, alább részletezett jelenségeket, amelyeket az 1990-es évekbeli magánositási folyamattól kezdődően a szakmai közbeszéd a magánszektor müködése szempontjából lényegesnek tartott, de eddig nem történt meg azok megerősitése, cáfolata, vagy elterjedésük mértékének megállapítása.

A magyarországi magánerdők egyik jellegzetessége a közös tulajdon, amely a magánosítás során alkalmazott eljárások eredménye, de az öröklések miatt azóta is létrejönnek közös tulajdonú földrészletek. A közös tulajdon elterjedésének meghatározása mellett jelen írás célja az is, hogy további mutatókkal jellemezze a közös tulajdonokat, különös tekintettel a döntéshozási képességet befolyásoló jellemzőkre. Ez utóbbi szempont jelentőségét az adja, hogy a kedvezőtlen tulajdonviszonyokat sokszor jelölik az erdőgazdálkodók megalakulása előtt álló gátló tényezőként.

A tulajdonszerkezet kedvezőtlen tulajdonságainak, például az elaprózottságnak és a szétszórtságnak az elsődleges okozójaként a szakmai közvélekedés a magánosítás során alkalmazott módszereket jelöli meg. Szintén konszenzusos vélemény, hogy az öröklések jelentősen hozzájárulnak a magán erdőtulajdon további elaprózódásához, és a közös tulajdonok tulajdonosi létszámának növekedéséhez. A másik lényeges földforgalmi tényező az adásvétel, amellyel kapcsolatban az egyik gyakori feltételezés, hogy a földforgalom alacsony, az adás-vételek nem képesek érdemben befolyásolni a tulajdonszerkezetet. Emellett szintén gyakori jelenségként írják le azt a tulajdonosi magatartást, hogy egy tulajdonostárs a földrészleten belül a szótöbbséghez elegendő tulajdoni részesedés megszerzésével alakít ki domináns pozíciót.

A fentiek alapján a tanulmány célja, hogy kimutassa az öröklések és az adásvételek jelentőségét és hatásait, valamint tipizálja és elemezze a földrészletek tulajdonszerkezetét a tulajdoni illetőségek megoszlása alapján.

\section{ANYAG ÉS MÓDSZER}

Magán-erdőgazdálkodás alatt olyan erdőgazdálkodást érünk, amely jellemzően magánszemélyek és magántulajdonú vállalkozások tulajdonában levő erdőkön történik magánszemélyek és magántulajdonú vállalkozások által.

A 2009. évi XXXVII. törvény az erdőről, az erdő védelméröl és az erdőgazdálkodásról (Evt.) $6 \S$ meghatározza az erdő fogalmát, amelynek sarkalatos eleme, hogy erdőnek az 
Országos Erdőállomány Adattárban (adattár) szereplő területek minősülnek. A 109/1999 (XII. 29.) FVM rendelet az ingatlan-nyilvántartásról szóló 1997. évi CXLI. törvény végrehajtásáról 47 § meghatározása szerint az Evt. által erdőnek minősülő területeket erdő művelési ágban kell nyilvántartani. Ezek alapján a jogszabályi környezet biztosítja, hogy az ingatlannyilvántartás és az adattár azonos módon tartalmazza az erdőket, de a valóságban ez mégsem teljesül.

Jelen vizsgálatok lefolytatásához 2015.10.20. aktualitással álltak rendelkezésre a Magyarországon, külterületi fekvésben található, nem a magyar állam 100\%-os tulajdonában levő, 0,5 hektárnál nagyobb kiterjedésű erdő művelési ágú alrészletet tartalmazó földrészletek tulajdonosi adatokkal kiegészített földkönyvi adatai. Ebben az adatbázisban szerepeltek olyan területek is, amelyek erdő művelési ágú alrészletet tartalmaznak, de az adattárban nem szerepelnek.

Nem részei a vizsgált adathalmaznak a fentiek szerint azon erdőterületek, amelyeket az adattár erdőként tart nyilván, de a földkönyvi nyilvántartás szerint a művelési águk nem erdő.

A cikk további részeiben Magyarország erdei és a vizsgált erdőterület, valamint a hagyományosan magánszektornak hívott erdőterület és az elemzésbe vont erdőterület közötti különbségekre nem lesz utalás, de az eredményeket az eltérések tudatában kell értékelni és esetlegesen felhasználni.

A vizsgálati adathalmaz 143311 földrészletet, 978241 tulajdoni illetőséget és 847039 hektár erdőterületet tartalmaz. A vizsgálatba vont területeket, valamint a vizsgálatból a fekvése vagy mérete miatt kizárt területek adatait az 1 . táblázat mutatja be.

A vizsgált adathalmazban a földrészleteken belüli erdőterületek alatt az erdő művelési ágú alrészletek területét kell érteni.

1. táblázat: $A$ vizsgált adathalmaz jellemzői.

Table 1: Description of the analyzed dataset.

\begin{tabular}{|l|c|c|c|c|}
\hline Kritériumok & $\begin{array}{c}\text { Földrészletek } \\
\text { száma } \\
\text { (db) }\end{array}$ & $\begin{array}{c}\text { Földrészlet } \\
\text { teljes területe } \\
\text { (ha) }\end{array}$ & $\begin{array}{c}\text { Földrészletek } \\
\text { erdöterülete } \\
\text { (ha) }\end{array}$ & $\begin{array}{c}\text { Tulajdoni } \\
\text { illetöségek } \\
\text { száma } \\
\text { (db) }\end{array}$ \\
\hline $\begin{array}{l}\text { Erdő művelési ágban } \\
\text { nyilvántartott összesen }\end{array}$ & 277964 & 1904324 & 879794 & 1337220 \\
\hline $\begin{array}{l}\text { összesböl belterület és } \\
\text { zártkert }\end{array}$ & 65259 & 30057 & 15712 & 152537 \\
\hline $\begin{array}{l}\text { összesből 0,5 ha-nál } \\
\text { kisebb }\end{array}$ & 129540 & 163195 & 23591 & 206442 \\
\hline Vizsgált adatbázis & 143311 & 1724910 & 847039 & 978241 \\
\hline
\end{tabular}




\section{VIZSGÁLATOK}

\section{Földrészleteken belüli erdőterületek méreteloszlása}

Mivel a vizsgált adathalmaz csak a legalább 0,5 ha erdőterületü földrészleteket tartalmazza, ezért a legkisebb érték 0,5 hektár, míg az egy földrészleten belüli legnagyobb erdöterület 458 hektár. A földrészletek méret szerinti gyakorisági és területi eloszlásait a 2. táblázat mutatja be.

2. táblázat: A földrészletek erdőterületének és darabszámának eloszlása a földrészletek erdőterülete szerinti kategóriákban (a felső csoporthatárok nem tartoznak a csoporthoz).

Table 2: Distribution of the forest area and the number of land lots over the size classes of forest area within the land lots (upper limits are not included in the groups).

\begin{tabular}{|c|c|c|}
\hline $\begin{array}{c}\text { Erdőterület nagysága a } \\
\text { földrészleten belül } \\
\text { (ha) }\end{array}$ & $\begin{array}{c}\text { Összes } \\
\text { erdöterület } \\
\text { (ezer ha) }\end{array}$ & $\begin{array}{c}\text { Összes } \\
\text { földrészlet } \\
\text { (ezer db) }\end{array}$ \\
\hline $0,5-1$ ha & 25,0 & 34,7 \\
\hline $1-2,5$ ha & 68,8 & 42,7 \\
\hline $2,5-5$ ha & 91,8 & 25,8 \\
\hline $5-10$ ha & 135,0 & 19,1 \\
\hline $10-25$ ha & 230,0 & 14,9 \\
\hline $25-50$ ha & 153,0 & 4,5 \\
\hline $50-100$ ha & 92,7 & 1,4 \\
\hline $100-150$ ha & 18,5 & 0,1 \\
\hline $150-250$ ha & 25,1 & 0,2 \\
\hline 250 ha- & 8,4 & $<0,1$ \\
\hline Összesen & 847,039 & 143,311 \\
\hline
\end{tabular}

A földrészletek erdőterületének és darabszámának a földrészletek mérete szerinti halmozott eloszlását az 1. ábra szemlélteti, amelyböl látható, hogy a földrészletek fele 2,2 hektárnál kisebb erdőterületet tartalmaz, amely az összes erdőterület mintegy $10 \%$-át teszi ki. Az erdőterület fele olyan földrészletben található, amelyek erdőterülete 15,3 hektárnál kisebb, és ezek az erdőterületek magukban foglalják a földrészletek $91 \%$-át.

A vizsgált adatbázisban 34273 olyan földrészlet található, amely az erdő mellett más művelési ágú földrészletet is tartalmaz. Ezen földrészletekben az erdő művelési ágú alrészletek területe összesen 219 ezer hektár, a nem erdő müvelési ágú alrészletek területe pedig 
272 ezer hektár. Ezekböl az adatokból látható, hogy ezekben a vegyes művelési ágú földrészletekben legtöbbször a nem erdő művelési ág dominál.

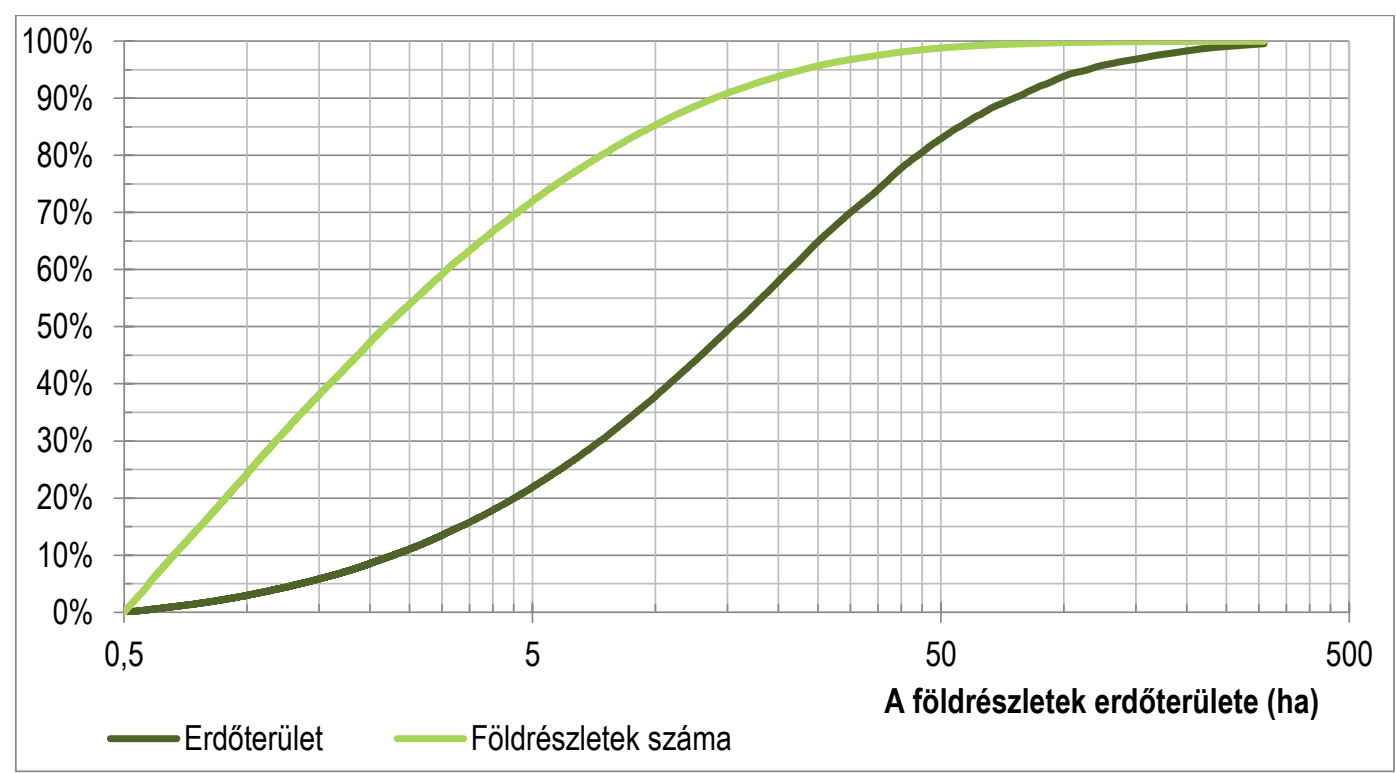

1. ábra: A földrészletek erdőterületének és darabszámának halmozott eloszlása a földrészleteken belüli erdöterület nagysága szerint, logaritmikus skálán ábrázolva.

Figure 1: Cumulative distribution of the number of land lots and the forest area of the land lots over the size of forest area within land lots on logarithmic scale.

A 2. ábra szemlélteti a különböző erdőterületü földrészletekben a nem erdő müvelési ágú alrészletek területét, valamint annak megoszlását müvelési ágak szerint. Látható, hogy öszszességében a szántó a legjellemzőbb ezek közül, és föként a kisebb erdőterülettel rendelkező földrészleteken jellemző ez a földhasználat. Ez az esetek többségében a szántó szélén húzódó erdősávokat jelenti, de előfordulnak kisebb erdőfoltok is. A második leggyakoribb kategóriát a gyep jellegü művelési ágak (gyep, legelő, rét) adják, amelyek csökkenő mértékben, de növekvő arányban jelennek meg az egyre nagyobb erdőterületek mellett. Ezek a kis erdőterületü földrészletek legelőt, kaszálót takarnak, melyek esetenként nagyobb jelentőséggel bírnak a mellettük található erdőnél. A nagyobb erdős alrészletek esetében gyakran erdei tisztásokról, vagy erdő menti kisebb kaszálókról van szó.

A további müvelési ágak jelentősége a területüknél fogva alacsonyabb, azonban a müvelésböl kivett területek, még ha kicsik is, komoly jelentőséggel bírhatnak egy adott földrészlet értékének megállapításakor. Lehetnek ezek erdei környezetben fekvő építési telkek, épületek vagy ipari létesítmények területei, amelyek jelentős értéket képviselhetnek kis területük ellenére. 


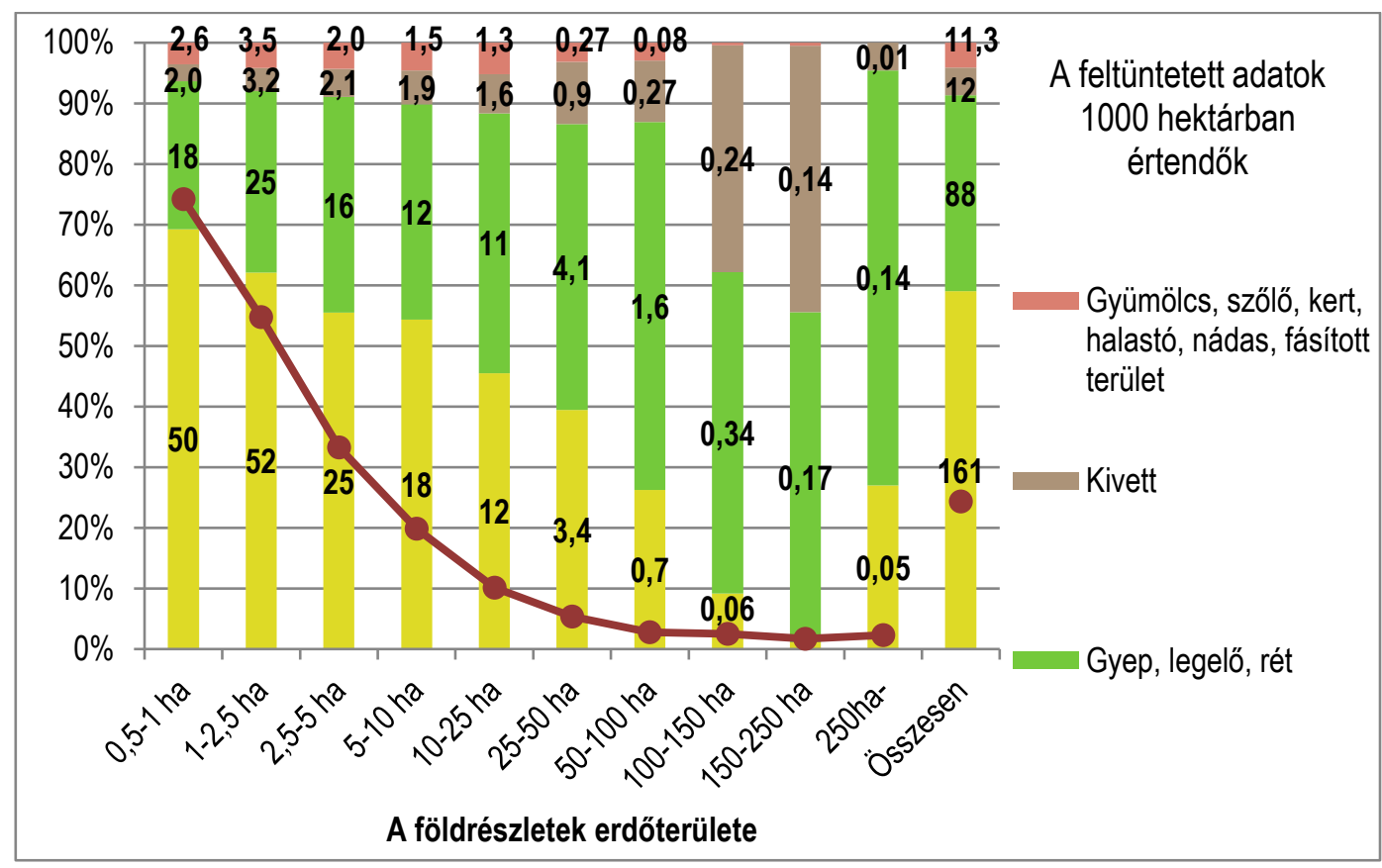

2. ábra: A nem erdő müvelési ágú területek egymáshoz és a teljes földrészlet területéhez viszonyított aránya a földrészletek erdőterülete alapján képzett kategóriákban és a teljes területen (a felső csoporthatárok nem tartoznak a csoporthoz).

Figure 2: The proportion of non-forest land use forms to the total area of non-forest land use forms and to the total area of land lots within categories based on the forest area of land lots (upper limits are not included in the groups).

\section{Tulajdonosok száma földrészleten belül}

A földrészletek darabszámának 52\%-a 1/1-es tulajdonú, amely az erdőterület 35\%-át teszi ki. A több, de legfeljebb 5 tulajdonosú földrészletek az összes erdőterület darabszámának 29\%-át alkotják az erdőterület 26\%-át fedve le. Az erdőterület 17\%-án 25-nél több tulajdonos található a földrészleten belül. Ez a földrészleteknek kevesebb, mint az 5\%-a, amelyek átlagos földrészletenkénti erdőterülete 21,5 hektár. 


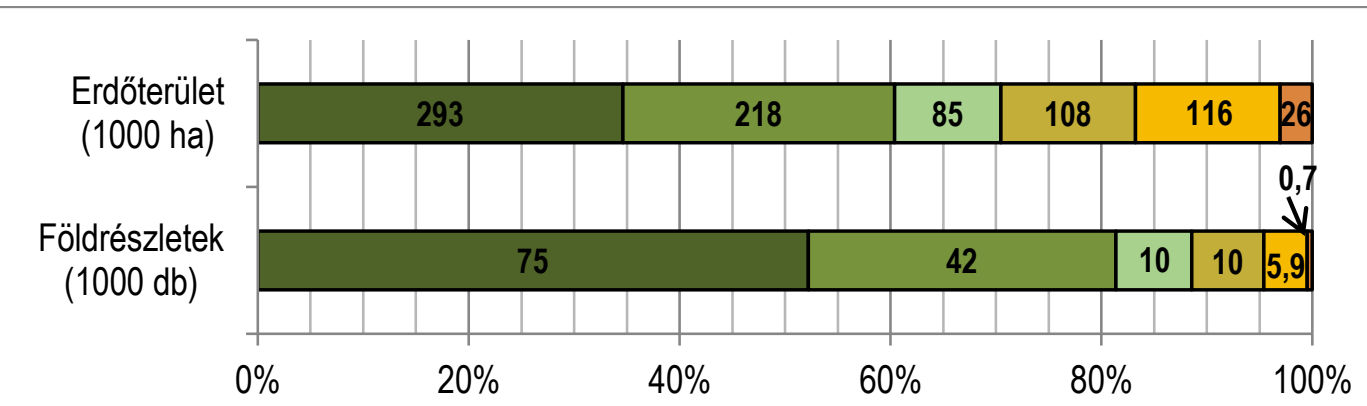

$\square 1$ tulajdonos $\square$ 2-5 tulajdonos $\square$ 6-10 tulajdonos $\square$ 11-25 tulajdonos $\square$ 26-100 tulajdonos $\square$ 100- tulajdonos

3. ábra: A földrészletek erdőterületének és darabszámának megoszlása a földrészletek tulajdonosainak száma alapján képzett csoportokban.

Figure 3: Relative frequency distribution of the forest area and the number of land lots over the classes of land lots by number of owners.

\section{Tulajdoni illetőségek eloszlása}

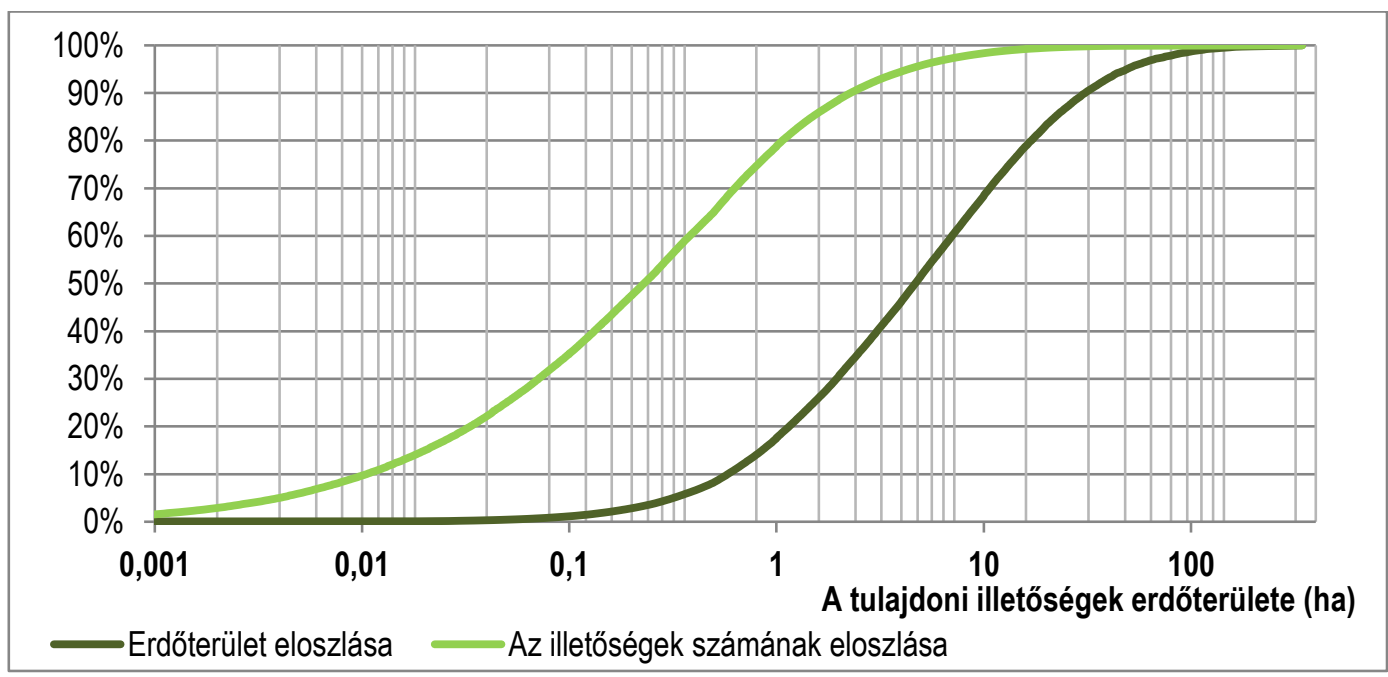

4. ábra: A tulajdoni illetőségek erdőterületének és darabszámának halmozott relatív eloszlása az illetőségek erdőterülete szerint.

Figure 4: Cumulative relative distribution of the number of ownership titles and their forest area over the forest area of the ownership titles.

A tulajdoni illetőségek (jelen esetben az egy földrészleten belül egy tulajdonoshoz tartozó erdőterületet értjük ezalatt, akkor is, ha az több bejegyzett illetőségből tevődik össze) az 1 ezred $\mathrm{m}^{2}$ és 350 hektár közötti tartományban szóródnak. A tulajdoni illetőségek átlagos 
mérete 0,9 hektár. Az illetőségek fele 0,23 hektárnál kisebb területü, amely az erdőterület 3,3\%-át teszi ki. Az 1 hektárt elérő tulajdoni illetőségeknek a darabszám tekintetében 20\%os részesedése van, a területnek viszont $82 \%$-át adják.

A tulajdoni illetőség mértéke a tulajdonnal kapcsolatos döntésekben figyelembe veendő szavazatarányt is meghatározza. Az

5. ábra alapján látható, hogy az illetőségeknek közel 60\%-a 1/20 (5\%) résznél kisebb szavazatarányt biztosít. Azon esetek, ahol nem egy tulajdonosa van a földrészletnek, de egy tulajdonos illetősége meghaladja a 0,5-öt, az összes illetőség mindössze 3\%-át adják, de magukba foglalják a teljes erdőterület 13\%-át, vagyis ezek az illetőségek az átlagnál négyszer nagyobbak.

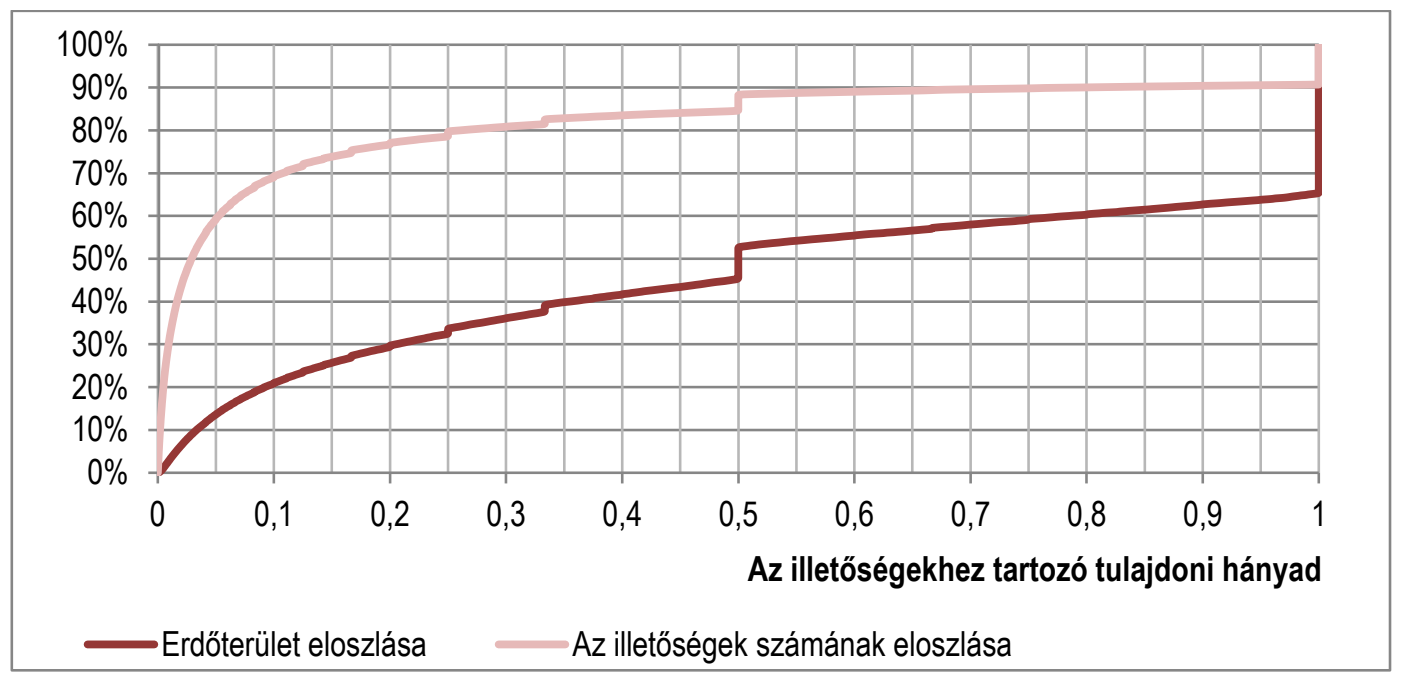

5. ábra: A tulajdoni illetőségek erdőterületének és számának halmozott relatív eloszlása az illetőséghez tartozó tulajdoni hányadok szerint.

Figure 5: Cumulative relative distribution of the number of ownership titles and their forest area over the property ratio of the ownership titles.

\section{Tulajdoni illetőségek szerzési jogcíme}

A tulajdoni illetőségek szerzési jogcímei alapján megállapitható az erdő művelési ágat érintő földforgalom jellege. Az adatok tisztább értelmezhetősége érdekében a szerzési jogcímek eloszlásának elemzésében csak a magánszemélyek tulajdonai szerepelnek. Ennek oka, hogy a magyar állam, az önkormányzatok és egyéb közszférába sorolható szervezetek a vizsgálatba csak kényszerüségböl kerültek be, elsősorban a vegyes tulajdonokon keresztül, másodsorban pedig mert technikailag nem voltak elkülöníthetök. A közszféra szereplöinek motivációi eltérnek a magánszféra szereplőinek motivációitól. A magánszektorhoz tar- 
tozó, de gazdasági formában működő tulajdonosok tulajdoni illetőségei azért nem szerepelnek ebben a vizsgálatban, mert 2001 óta már nem szerezhetnek további tulajdont. Az így szükített vizsgálati sokaság 953 ezer darab tulajdoni illetőséget tartalmaz, amelyek teljes erdőterülete 788 ezer hektár.

A 6. ábra adatai alapján elmondható, hogy a magánositási folyamatban szerzett tulajdoni illetőségek a darabszám 33\%-át teszik ki, de a területi részesedésük csak $27 \%$. Az öröklés útján szerzett tulajdoni illetőségek az előzőhöz hasonlóan $35 \%$ darabszám szerinti részesedést érnek el, területarányuk viszont csak $17 \%$. Az adásvételek és az ajándékozás jogcímeken bejegyzett tulajdoni illetőségek darabszám szerinti aránya 18\%, illetve $8 \%$, területarányuk pedig $35 \%$, illetve $12 \%$. A csere mind darabszám, mind területi arányát tekintve $5 \%$ alatti részesedéssel rendelkezik.

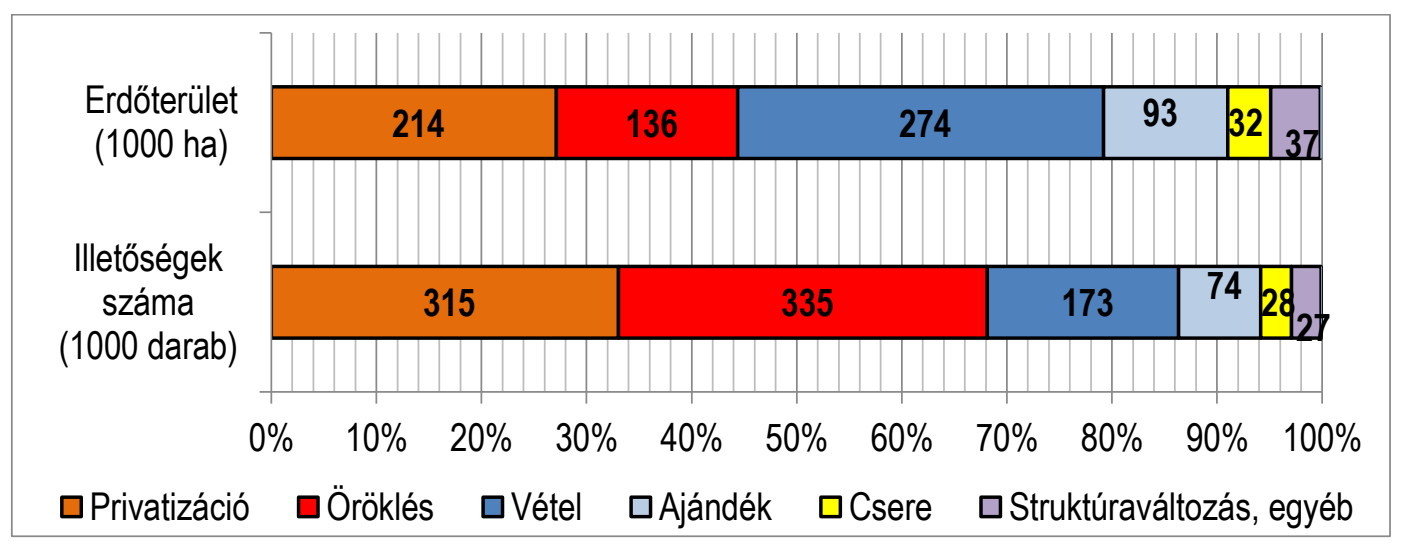

6. ábra: A magánszemélyek tulajdonában álló tulajdoni illetőségek darabszámának és erdőterületének relatív eloszlása szerzési jogcím szerint.

Figure 6: Relative frequency distribution of the number of ownership titles and the forest area over title deed types.

\section{Döntéshozatal a földrészleteken belül}

A földrészletek tulajdonosainak száma alapján közvetve jellemezhető a döntéshozatal nehézsége. A rendelkezésre álló adatbázis arra is alkalmas, hogy a különböző döntési szintek - mint például az egyszerű többség (>50\%) - eléréséhez megadjuk a legkisebb szükséges létszámot, amelyet a legnagyobb tulajdonosi illetőségek figyelembevételével kaphatunk meg. Az 7. ábra bemutatja, hogy a földrészletek $66 \%$-ában egyetlen személy is elegendő az $50 \%$-os szavazatarány átlépéséhez, amely az erdőterület 53\%-át teszi ki. A 2-5 fö legnagyobb tulajdonos egyetértésével elérhető $50 \%$-os tulajdoni arány a földrészletek $30 \%$-át és az erdőterület 35\%-át jellemzi. A legalább hat tulajdonos egyetértésével létrehozható többségi vélemény a földrészletek darabszám szerinti $4 \%$-án, terület szerint pedig 13\%-án fordul elő. 


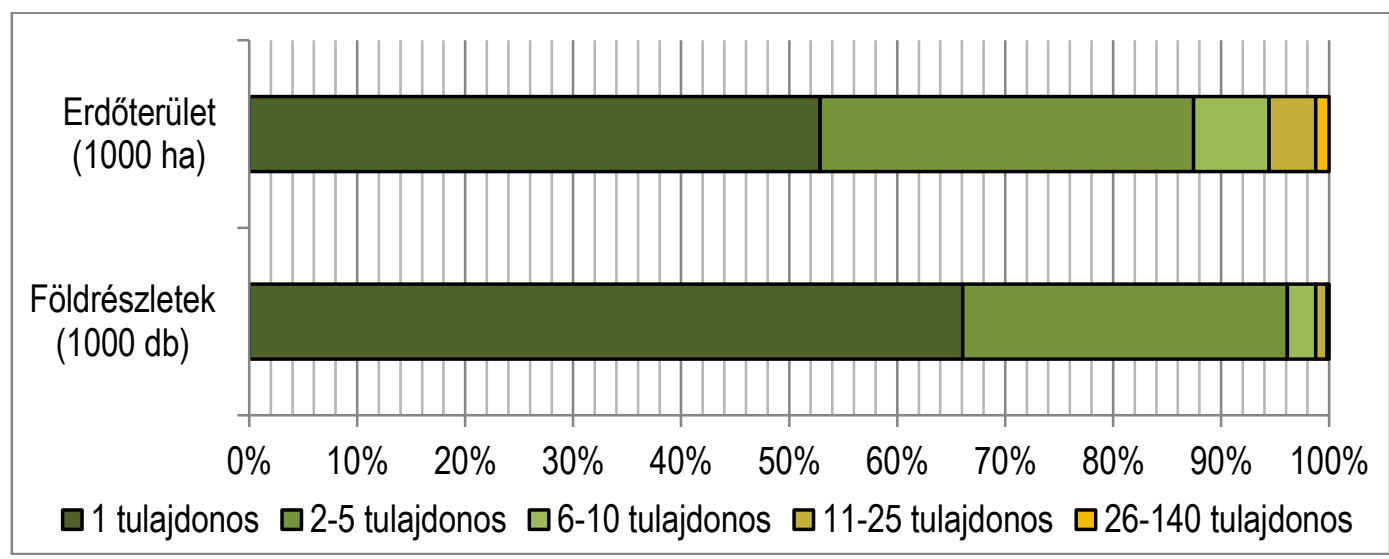

7. ábra: A földrészletek erdőterületének és darabszámának relativ eloszlása az 50\%-os szavazati arány meghaladásához szükséges legkevesebb tulajdonos száma szerint.

Figure 7: Relative frequency distribution of the number and the area of the land lots over the minimum number of owners to exceed $50 \%$ voting ratio (with and without land lots of a single owner).

\section{Földrészleten belüli tulajdoni koncentráció}

A tulajdonszerkezet koncentráltsága alatt jelen esetben a tulajdoni illetőségek méreti különbözőségét kell érteni. A földrészleteken belül a tulajdoni illetőségek megoszlásának jellemzésére jelen írás a legkisebb és legnagyobb méretü tulajdoni illetőség között arányt használja. Ezen jellemző szerint az alábbi csoportokba történt a földrészletek besorolása:

- egytulajdonosú: a földrészletnek egyetlen tulajdonosa van

- kiegyenlített tulajdonszerkezet: a legkisebb és a legnagyobb tulajdoni illetőség közötti méretkülönbség kétszeres, vagy kisebb

- mérsékelten koncentrált: a legkisebb és a legnagyobb tulajdoni illetőség közötti arány nagyobb, mint kettő, de kisebb, mint tíz

- koncentrált tulajdonszerkezet: a legkisebb és a legnagyobb tulajdoni illetőség közötti különbség tízszeres, vagy nagyobb

A 3. táblázat bemutatja, hogy a kiegyenlített és a mérsékelten koncentrált tulajdoni szerkezettel rendelkező földrészletek mind darabszám szerint, mind terület arányában kisebb jelentőségüek. Ezzel szemben az egytulajdonosú és a koncentrált tulajdonszerkezetű földrészletek $35 \%$ és $39 \%$ területi részesedést érnek el. A lényegi különbség közöttük, hogy az egytulajdonosúak kisebb méretü földrészletek, a koncentrált tulajdonszerkezetü földrészletek pedig átlagfelettiek, ezért a darabszám szerinti arányuk $52 \%$ és $17 \%$. 
3. táblázat: A földrészletek darabszámának és erdőterületének gyakorisági és relatív gyakorisági eloszlása tulajdonszerkezeti csoportok szerint.

Table 3: Frequency and relative frequency distribution of the number and the forest area of land lots over categories of ownership structure type.

\begin{tabular}{|l|c|c|c|c|}
\hline $\begin{array}{l}\text { Tulajdonszerkezeti } \\
\text { csoport }\end{array}$ & $\begin{array}{c}\text { Földrészletek } \\
\text { száma } \\
(\mathrm{db})\end{array}$ & $\begin{array}{c}\text { Erdőterület } \\
(\mathrm{ha})\end{array}$ & $\begin{array}{c}\text { Darabszám } \\
\text { arány } \\
(\%)\end{array}$ & $\begin{array}{c}\text { Területarány } \\
(\%)\end{array}$ \\
\hline Egytulajdonosú & 74792 & 293355 & $52 \%$ & $35 \%$ \\
\hline Kiegyenlített & 25710 & 110962 & $18 \%$ & $13 \%$ \\
\hline $\begin{array}{l}\text { Mérsékelten } \\
\text { koncentrált }\end{array}$ & 18086 & 113176 & $13 \%$ & $13 \%$ \\
\hline Koncentrált & 24723 & 329545 & $17 \%$ & $39 \%$ \\
\hline Összesen & 143311 & 847039 & $100 \%$ & $100 \%$ \\
\hline
\end{tabular}

\section{EREDMÉNYEK ÉS MEGVITATÁSUK}

A földrészlet a föld és az ahhoz kapcsolódó tulajdoni, valamint használati nyilvántartás alapegysége. Kivételt csak az erdőgazdálkodó, mint az erdőgazdálkodási célú hasznositás jogosultjának a nyilvántartása jelent, amely az erdők nyilvántartási és az erdőgazdálkodás igazgatási és gazdálkodási alapegységén, erdőrészletenként történik. Ebből a szempontból lényeges ismeret a földrészletek mérete - a méretet a földrészleten belül erdöterületként értelmezve - amely befolyásolja egy esetleges beavatkozás hatékonyságát. Utalva az vizsgálatok leírásánál elmondottakra látható, hogy ha a földrészletek legnagyobb méretü 10\%át érinti egy beavatkozás, az az erdőterület közel $53 \%$-ára van hatással. Ellenkező irányban megközelítve, ha a földrészletek legkisebb $50 \%$-át érinti egy beavatkozás, akkor az erdőterület $10 \%$-ára van hatással.

A földtulajdont érintő tulajdonosi döntések meghozatala, vagy éppen meghozhatósága szempontjából a legfontosabb tényező a tulajdonosok száma a földrészleten belül. Ehhez társulnak még a tulajdonosok különböző jellemzői is, mint például a lakhely, kor, nem, a tulajdonosok közötti kapcsolat és a tulajdoni illetőség nagysága. Ez utóbbiak nem képezik jelen írás tárgyát. 
A földrészletek tulajdonosainak száma alapján megállapítható, hogy a közös tulajdon igen elterjedt, hiszen az erdőterület csaknem kétharmadára jellemző. Ezen belül a kezelhetőnek tekinthető legfeljebb 5 tulajdonosú területek hozzáadva az 1/1-es tulajdonú területekhez 62\%-ot tesznek ki, amely az eddigi szakmai közbeszéd alapján kialakult feltételezéshez képest kedvezőbb képet mutat. A 6-10 fö tulajdonos olyan átmenetet képez, amelynek adminisztrációja attól függően igényel jelentős, vagy kevésbé jelentős szervezési munkát, hogy a tulajdonosok milyen könnyen érhetők el, és mennyire motiváltak. 25 fö, vagy az azt meghaladó tulajdonosi létszám a tulajdonosok elérhetőségétől és hozzáállásától függetlenül akadályozó tényezőnek tekinthető. llyen esetekben az sem könnyíti lényegesen a szervezési feladatokat, ha a tulajdonosi illetőségek átlagos területe elfogadhatóan nagy, és azok vagyoni értéke a tulajdonosok számára megfelelő motivációt jelent. Az ilyen erődterületek aránya $17 \%$, amely önmagában nehezen minősithető soknak, vagy kevésnek, de egy tulajdonszerkezetet javítani szándékozó akcióprogram célterületét kell képezzék.

Jól látható az a tendencia, hogy minél nagyobb a földrészlet, általában annál több tulajdonosa is van. Ez a két mutató alapvetően ellentétes szerepet játszik a gazdálkodás megszervezése tekintetében, hiszen minél nagyobb a földrészlet (erdőterület), általában annál nagyobb értéket képvisel, viszont minél több a tulajdonos, annál nehezebb megszervezni a gazdálkodást és meghozni a gazdálkodói döntéseket, így az ilyen jellegü vizsgálatok esetében figyelembe kell venni e két mutató korrelációját.

Az erdőkkel mint ingatlanokkal kapcsolatos régi közkeletű vélemény (Márkus \& Mészáros 1997), hogy azok forgalma alacsony. Ez a magántulajdonú erdők esetén azért bír nagy jelentőséggel, mert a magánosítás során kialakult tulajdoni és tulajdonosi szerkezetre három fő folyamatnak lehet közvetlen és meghatározó hatása. Az egyik a közvetlen állami beavatkozás - amilyen a magánosítás is volt - de a magánositás óta ilyen nem történt, és nincs is kilátásban hasonló. A második a tulajdon, azaz a földrészletek megosztással vagy összevonással történő átalakitása, amelynek vizsgálatára a jelenlegi adatbázis nem alkalmas, és más forrásból sincs idevágó információ. A harmadik folyamat a tulajdoni tranzakciók, amelyek egymással ellentétes előjelü változásokat okoznak. Az idesorolható legfontosabb ügyletek az öröklés, az adásvétel, az ajándékozás és a csere.

Az adatok alapján látható, hogy a jelenlegi szabályozás, szokások és demográfiai helyzet mellett az örökléssel szerzett tulajdoni illetőségek átlag alatti méretüek, ami annak a következménye, hogy az öröklések által egyre kisebb tulajdoni illetőségek jönnek létre.

Az öröklések tulajdoni elaprózódást okozó hatásával ellenétesen hatnak az adásvételek, amelyekben az átlag feletti tulajdoni illetőségek vesznek részt, illetve az egy földrészleten belül megvásárolt több tulajdoni illetőség összevonásával átlag feletti méretű tulajdoni illetőségek keletkeznek.

A cserék és az ajándékozások hatása semleges, de átlag feletti tulajdoni illetőségek esetén jelennek meg.

A tulajdon hasznositásával kapcsolatos legelső döntéseket földrészlet szinten kell meghozni, és a közös tulajdonban álló földrészletek esetében ez egy kritikus kérdés, hiszen a 
gazdálkodás alapját a tulajdonosi döntés határozza meg. A tulajdonosok és az erdőgazdálkodó között létrehozandó jogviszonytól függöen sokféle döntésre lehet szükség, amelyek különböző szavazattöbbséget igényelhetnek. Az egyszerủ szótöbbség az előforduló legalacsonyabb szavazattöbbség, ezért e cikk ezt jelölte ki vizsgálati értékként. A földrészletek több mint kétharmadán az egyszerű szótöbbség eléréséhez egyetlen tulajdonos szükséges, amely nem meglepö, hiszen a földrészletek $52 \%$-ának egyetlen tulajdonosa van. Az egy tulajdonosú földrészletek területaránya 35\%, míg az egy tulajdonos által elérhető $50 \%$-os tulajdoni arány a terület 53\%-án jellemző. Azok az esetek tehát, ahol a nem 1/1-es tulajdonosú földrészleteken egyetlen tulajdonos meghaladja az 50\%-os tulajdoni arányt, a földrészletek 14\%-át, és az erdőterület 18\%-át érinti. A földrészletek $96 \%$-án, és az erdőterület $87 \%$-án az 50\%-os tulajdoni arány a legfeljebb 5 fő legnagyobb tulajdoni aránnyal rendelkező tulajdonos egyetértésével elérhető. $A 6$ fö feletti legnagyobb tulajdonosok egyetértésével létrehozható egyszerü többség az erdőterület 13\%-án fordul elő, amely nem tűnik jelentősnek. Figyelembe kell azonban venni, hogy az ilyen tulajdonszerkezet, már komoly szervezőmunkát igényel, és itt csak egy olyan ideális állapotból indulunk ki, hogy a legnagyobb tulajdonosok egyet is értenek egymással. Amennyiben a döntéshozatali nehézségek az erdőgazdálkodó megalakulásának, vagy kijelölésének az útjában állnak, és ez az un, „rendezetlenség" jelenségének kiváltó oka lehet, akkor már a 13\%-os területarány jelentősnek minősül.

Mind a földrészletenkénti tulajdonosi létszámok, mind a döntési szituációk értékelésekor fontos figyelembe venni, hogy az erdőgazdálkodó megszervezése és müködése sokesetben nem egyetlen földrészletre terjed ki. Emiatt az itt meghatározott küszöbértékek csak akkor állják meg a helyüket, ha a döntések meghozatala egyetlen földrészletet érint. Olyan gazdálkodók esetében, mint például az erdőbirtokossági társulatok, amelyek a döntéseiket a gazdálkodásba vont földrészletek egészére hozzák meg az érintett összes tulajdonos részvételével, az itt alkalmazott küszöbértékek nem relevánsak.

A tulajdonszerkezet egyenlötlenségei sokféle nézőpontból vizsgálhatók, amelyek közül a koncentráció vizsgálata történt meg a legkisebb és a legnagyobb tulajdoni illetőség arányával jellemezve. Ez az elemzés azért ezt a mutatót használja, mert az ebből a szempontból képzett csoportok osztályozó kritériumai könnyen értelmezhetők. Más mutatók esetén a teljes eloszlás jobban jellemezhető, de az osztályok kialakitásához nehezebben azonosithatók a kritikus értékek, és azok az olvasó számára nehezebben is értelmezhetők.

A tulajdoni illetőségek földrészleten belüli eloszlása arra világít rá, hogy a földrészleten belül a tulajdonosok milyen viszonyban vannak egymással, mekkora a tulajdonosok közötti szavazati arányok eltolódása. A földrészleten belüli tulajdoni arányok minél egyenlőtlenebbül oszlanak meg, annál nagyobb az esély arra, hogy a nagyobb tulajdonosok a kisebb tulajdonosokat dominálhatják, és ilyen módon a kisebbségi tulajdonosok hátrányba kerülhetnek olyan esetekben, amikor nincs szükség 100\%-os tulajdonosi egyetértésre, vagy a tulajdonosoknak nincs ésszerü módon alkalmazható vétó lehetőségük. 
Az egytulajdonosú földrészletek elterjedési mértékei fent már megjelentek, ezek jelentik a leginkább letisztult tulajdoni szerkezetet. A kiegyenlített tulajdoni szerkezetben jellemzően kevés tulajdonos van, és ezek tulajdoni arányai között a különbségek nem olyan nagyok, hogy egyes tulajdonosok szándékai figyelmen kívül hagyhatók lennének. Az ilyen földrészletek darabszám szerinti aránya 18\%, területarányuk pedig 13\%, amely értékek mutatják, hogy ez a tulajdonszerkezet az átlag alatti méretü földrészletekben fordul elö. A közel azonos tulajdoni arányok megjelenése sok esetben az öröklésekhez köthető, mivel a főszabályok szerinti öröklés esetén gyakori a több, azonos méretű tulajdoni illetőség megjelenése. A kifejezetten koncentrált földrészletek - ahol a legnagyobb és a legkisebb tulajdoni illetőség között tízszeres a különbség - darabszám szerinti részesedése 17\%, területarányuk pedig $39 \%$. Ezek az értékek mutatják, hogy kifejezetten az átlag feletti földrészletekben fordul elő, hogy a tulajdonosok száma magas, és a tulajdoni illetőségek közötti különbség felveti annak lehetőségét, hogy a kistulajdonosoknak nincs érdemi ráhatása a tulajdonnal kapcsolatos döntésekre.

\section{ÖSSZEFOGLALÁS}

A jelen tanulmány a bemutatott eredményekkel a magán-erdőgazdálkodás alapjait jelentő tulajdoni szerkezettel kapcsolatos kiemelkedően fontos adatokat közöl, valamint a szakmai közbeszédben gyakran előforduló egyes vélekedéseket erősit, illetve cáfol meg. Ezek tételesen:

- Megerösítést kapott, hogy a közös tulajdon a magyarországi magán-erdőgazdálkodásban egy jellemző jelenség, területi kiterjedése $65 \%$, a földrészleteknek pedig 48\%-át érinti. Ez felhívja a figyelmet arra, hogy a jelenség gazdálkodásra, és egyáltalán a tulajdonnal való rendelkezési lehetőségekre gyakorolt hatását vizsgálni kell, és az erdészeti politikának ezt figyelembe kell venni.

- Jelen tanulmány pontos adatokat közöl a földrészletenkénti tulajdonosi létszámról, amely alapján elmondható, hogy a földrészletek $81 \%$-án 5 fönél kevesebb tulajdonos van, amely a magán-erdöterület $60 \%$-át teszi ki.

- A vizsgálatok alapján megállapítható, hogy amennyiben egyszerü többségü tulajdonosi döntéshozatalra van szükség, akkor a földrészletek $96 \%$-ában, és ezzel a magán-erdőterület $87 \%$-án a földrészletenként számított 5 legnagyobb tulajdonos egyetértésével a többségi vélemény kialakitható.

- Az eredmények megerősítették, hogy a tulajdoni illetőségek az ezred négyzetméter és a többszáz hektár közötti tartományban szóródnak, és a teljes vizsgált erdőterületet figyelembe véve jelentősen koncentrálódnak.

- Megállapítást nyert, hogy a koncentrált tulajdonszerkezetü földrészletek átlagosnál nagyobb méretüek, és területarányuk $39 \%$. 
- Az eredmények alapján cáfolható, hogy a magán-erdőterület aktív földforgalma alacsony. A magánszemély tulajdonosok tulajdonában levő magán-erdőterület 35\%-át vétel jogcímen jegyezték be.

- Az eredmények megerősítették a szakmai közbeszédben általánossá vált vélekedést, hogy az öröklés jelentős földforgalmi tényező, és kimutathatóan a tulajdon elaprózódásával jár.

\section{KÖSZÖNETNYILVÁNÍTÁS}

A szerzök köszönetüket fejezik ki a Földmérési és Távérzékelési Intézetnek az adatszolgáltatással kapcsolatos együttmüködésért és a Földművelésügyi Minisztériumnak a kutatási program támogatásáért.

\section{HIVATKOZÁSOK}

Hogl K., Pregernig M. \& Weiss G. 2005: What is New about New Forest Owners? A Typology of Private Forest Ownership in Austria. Small-Scale Forest Economics, Management and Policy 4(3): 325-342.

DOI: $10.1007 / s 11842-005-0020-y$

Jáger L. 2001: A magán-erdőtulajdonosok véleménye és ismeretei. Doktori értekezés, Sopron, Nyugat-magyarországi Egyetem, 2001.

Lett B., Gál J., Stark, M., \& Frank N. 2016: Development and Possibilities for Close-to-Nature Forest Resource Management in Hungary. Acta Silvatica et Lignaria Hungarica 12(1): 55-73. DOI: 10.1515/aslh-2016-0006 Márkus L. \& Mészáros K. 1997: Erdőérték-számítás, az erdőértékelés alapjai, Mezőgazdasági Szaktudás Kiadó, Budapest.

Mészáros K. 2001: A városi erdőtulajdonosok vizsgálata Magyarországon, Országos Kiemelésű Társadalomtudományi Kutatások Alapítvány, Budapest.

NÉBIH 2016: Nemzeti Élelmiszerlánc Biztonsági Hivatal: Beszámoló az erdősítésekről és a fakitermelésekről a 2015. évben.

Páll M. 1997: Az erdőterületek árverési adatainak vizsgálata Zala megyében. Erdészeti Lapok 132(5): 141142.

Schmithüsen F. \& Hirsch F. 2008: Private Forest Ownership in Europe - Advance Draft March 2008. United Nations Publications, Geneva.

Érkezett: 2017. március 21.

Közlésre elfogadva: 2017. június 23. 